\title{
The decrease in mid-stratospheric tropical ozone since 1991
}

\author{
G. E. Nedoluha ${ }^{1}$, D. E. Siskind ${ }^{1}$, A. Lambert ${ }^{2}$, and C. Boone ${ }^{3}$ \\ ${ }^{1}$ Naval Research Laboratory, Washington, D. C., USA \\ ${ }^{2}$ Jet Propulsion Laboratory, California Institute of Technology, Pasadena, California, USA \\ ${ }^{3}$ Department of Chemistry, University of Waterloo, Waterloo, Ontario, Canada
}

Correspondence to: G. E. Nedoluha (nedoluha@ nrl.navy.mil)

Received: 10 November 2014 - Published in Atmos. Chem. Phys. Discuss.: 7 January 2015

Revised: 24 March 2015 - Accepted: 3 April 2015 - Published: 23 April 2015

\begin{abstract}
While global stratospheric $\mathrm{O}_{3}$ has begun to recover, there are localized regions where $\mathrm{O}_{3}$ has decreased since 1991. Specifically, we use measurements from the Halogen Occultation Experiment (HALOE) for the period 1991-2005 and the NASA Aura Microwave Limb Sounder (MLS) for the period 2004-2013 to demonstrate a significant decrease in $\mathrm{O}_{3}$ near $\sim 10 \mathrm{hPa}$ in the tropics. $\mathrm{O}_{3}$ in this region is very sensitive to variations in $\mathrm{NO}_{y}$, and the observed decrease can be understood as a spatially localized, yet long-term increase in $\mathrm{NO}_{y}$. In turn, using data from MLS and from the Atmospheric Chemistry Experiment (ACE), we show that the $\mathrm{NO}_{y}$ variations are caused by decreases in $\mathrm{N}_{2} \mathrm{O}$ which are likely linked to long-term variations in dynamics. To illustrate how variations in dynamics can affect $\mathrm{N}_{2} \mathrm{O}$ and $\mathrm{O}_{3}$, we show that by decreasing the upwelling in the tropics, more of the $\mathrm{N}_{2} \mathrm{O}$ can photodissociate with a concomitant increase in $\mathrm{NO}_{y}$ production $\left(\right.$ via $\mathrm{N}_{2} \mathrm{O}+\mathrm{O}\left({ }^{1} \mathrm{D}\right) \rightarrow 2 \mathrm{NO}$ ) at $10 \mathrm{hPa}$. Ultimately, this can cause an $\mathrm{O}_{3}$ decrease of the observed magnitude.
\end{abstract}

\section{Introduction}

The slowdown in the $\mathrm{O}_{3}$ decline and the beginnings of recovery of the ozone layer have been documented (Newchurch et al., 2003; Yang et al., 2006). Monitoring of the ozone layer continues to be critical in order to understand ozone recovery as the CFC (chloroflourocarbon) burden in the stratosphere decreases. A number of observational studies have quantified the global distribution of changes to the $\mathrm{O}_{3}$ layer and revealed distinct patterns and variability which show that $\mathrm{O}_{3}$ trends are not spatially uniform. One consistent result is that over decadal time scales, equatorial $\mathrm{O}_{3}$ in a vertical layer near $30 \mathrm{~km}$ (corresponding to $\sim 10 \mathrm{hPa}$ ) often varies very differently from $\mathrm{O}_{3}$ in the rest of the middle to upper stratosphere. Kryölä et al. (2013), using measurements from the Stratospheric Aerosol and Gas Experiment (SAGE) from 1984 to 1997 , show a general decrease in $\mathrm{O}_{3}$ which is statistically significant over much of the stratosphere, but an increase in equatorial $\mathrm{O}_{3}$ (albeit not statistically significant) in the 30-35 km region. Conversely, for the period $1997-$ 2011 Kryölä et al. (2013) show a general increase in $\mathrm{O}_{3}$ from SAGE and Global Ozone Monitoring by Occultation of Stars (GOMOS) measurements, but a statistically significant decrease near $30 \mathrm{~km}$ in the tropics. Bourassa et al. (2014) combine SAGE measurements with measurements from the Optical Spectrograph and InfraRed Imager System (OSIRIS) instrument and, again splitting the data into pre- and post-1997 periods, find very similar results. Damadeo et al. (2014) compute a SAGE trend from 1998 to 2005 and find a positive trend near $30 \mathrm{~km}$ in the tropics and Northern Hemisphere, but a negative trend in the Southern Hemisphere at this level. Measurements from the Scanning Imaging Absorption Spectrometer for Atmospheric Chartography (SCHIAMACHY) instrument for the period 2002-2012, reported by Gebhardt et al. (2014), show a pattern similar to the 1997-2011 pattern reported by Kryölä et al. (2013), i.e., a strong statistically significant decrease in tropical $\mathrm{O}_{3}$ in the $30-35 \mathrm{~km}$ region, while most of the middle atmosphere shows a slight increase in $\mathrm{O}_{3}$. Finally, Eckert et al. (2014) using Michelson Interferometer for Passive Atmospheric Sounding (MIPAS) data from 2002 to 2012, also show a general increase in $\mathrm{O}_{3}$ in most regions, but find statistically significant negative trends in the tropics from $\sim 25$ to $5 \mathrm{hPa}$. Eckert et al. (2014) note that increased upwelling has been suggested as an explanation for ozone decreases, but, in referring to these trends, they conclude that 
"upwelling does not provide a sufficient explanation for the negative values in the tropical mid-stratosphere."

Ozone at $10 \mathrm{hPa}$ over the equator is particularly sensitive to catalytic cycles involving the odd nitrogen $\left(\mathrm{NO}_{y}\right)$ chemical family (Olsen et al., 2001; Brasseur and Solomon, 1986). Ravishankara et al. (2009) showed that $\mathrm{N}_{2} \mathrm{O}$ would be the dominant ozone depleting substance emitted in the 21 st century, and pointed out that nitrogen oxides contribute most to $\mathrm{O}_{3}$ depletion just above where the $\mathrm{O}_{3}$ mixing ratios are the largest. Portmann et al. (2012) calculated the effects of a surface boundary increase of 20 ppbv of $\mathrm{N}_{2} \mathrm{O}$ (an increase expected over $\sim 20$ years in the IPCC A1B scenario) on $\mathrm{O}_{3}$. They showed that this increase in $\mathrm{N}_{2} \mathrm{O}$ emission would lead to a global mean decrease of $\sim 0.5-0.7 \%$ in $\mathrm{O}_{3}$ just above the peak of the ozone mixing ratio $\left(0.1 \mathrm{DU} \mathrm{km}^{-1}\right.$ in the $30-$ $35 \mathrm{~km}$ region where $\mathrm{O}_{3}$ has a density of $\sim 15-20 \mathrm{DU} \mathrm{km}^{-1}$ based on their Fig. 2). In mixing ratio terms, this gives a rate of $\sim 5-7 \mathrm{ppbv} \mathrm{yr}^{-1}$. Plummer et al. (2010) studied $\mathrm{O}_{3}$ changes in a model including GHGs (greenhouse gases) and ODSs (ozone-depleting substances). They ran two experiments with a faster Brewer-Dobson circulation, and these two experiments showed, at $10 \mathrm{hPa}$ in the tropics, a decrease in reactive nitrogen and an increase in both $\mathrm{O}_{3}$ and $\mathrm{N}_{2} \mathrm{O}$ at $10 \mathrm{hPa}$ relative to the experiments with a slower circulation. Thus variations in $\mathrm{O}_{3}$ and $\mathrm{N}_{2} \mathrm{O}$ at $10 \mathrm{hPa}$ can be either correlated or anti-correlated depending upon whether they are driven primarily by circulation or by changes in $\mathrm{N}_{2} \mathrm{O}$ entering the stratosphere.

In addition to long-term anthropogenically driven changes, events such as the eruption of Mt. Pinatubo may alter the chemistry and dynamics of the stratosphere for extended periods. Aquila et al. (2013) compared a reference model with a model which simulated the effect of the volcanic aerosols on both chemistry and dynamics. They calculated an increase in $\mathrm{O}_{3}$ of $\sim 2 \%$ at $10 \mathrm{hPa}$ in the tropics slightly more than a year after the eruption, with no strong latitudinal variation. Damadeo et al. (2014) attempt to disentangle anthropogenically driven changes from Pinatubo eruption driven changes using an aerosol based volcanic proxy.

Previous observational work has correlated $\mathrm{O}_{3}$ interannual variability in the tropics near $10 \mathrm{hPa}$ with changes in specific odd nitrogen compounds; however, these studies were only for relatively short time periods compared with the $\mathrm{O}_{3}$ studies referenced above. Randel et al. (2000) showed that the Halogen Occultation Experiment (HALOE) observed increasing $\mathrm{NO}+\mathrm{NO}_{2}$ coincident with decreasing $\mathrm{O}_{3}$ from 1992 to 1997, but that these variations leveled-off during the last years of HALOE measurements which were then available (1998-2000). The rate of $\mathrm{O}_{3}$ decrease from 1992 to 1996 was faster than $100 \mathrm{ppbv} \mathrm{yr}^{-1}$ just above $10 \mathrm{hPa}$ in the tropics. The HALOE measurements of $\mathrm{NO}_{2}$ at $\sim 10 \mathrm{hPa}$ from 1993 to 1997 were shown to be consistent with a decrease in upward transport (Nedoluha et al., 1998) and increased photolysis of $\mathrm{N}_{2} \mathrm{O}$, the source of stratospheric $\mathrm{NO}_{y}$.
The present study extends the previous observational studies with a combination of 21 years of ozone data from the UARS (Upper Atmosphere Research Satellite) HALOE and the Aura Microwave Limb Sounder (MLS) measurements, plus nitrogen species data from HALOE, MLS and the Atmospheric Chemistry Experiment (ACE). Our results confirm the existence of the $10 \mathrm{hPa}$ tropical ozone trend anomaly and link it to a correspondingly consistent local change in the nitrogen species which affect $\mathrm{O}_{3}$. The resulting rate of change in $\mathrm{O}_{3}$ and in the nitrogen species is an order-of-magnitude faster than changes predicted from model calculations based upon changes in anthropogenic emissions.

\section{Measurements from HALOE, aura MLS, and ACE}

We make use of measurements from the HALOE, MLS, and the Fourier transform spectrometer measurements from ACE. HALOE measurements of $\mathrm{O}_{3}$, $\mathrm{NO}$, and $\mathrm{NO}_{2}$ are available from 1991 to 2005. HALOE used the solar occultation technique which provided $\sim 28-30$ profiles per day in two latitude bands, one at sunrise and one at sunset. The latitude bands drifted daily so that near global latitudinal coverage was provided in both sunrise and sunset modes five times over the course of a year. The trends in the HALOE $\mathrm{O}_{3}$ measurements have been compared against SAGE II (Nazaryan et al., 2005) and differences have been found to be on the order of less than $0.3 \%$ per year in a majority of latitude bands at $25,35,45$, and $55 \mathrm{~km}$.

MLS measurements of $\mathrm{O}_{3}$ and $\mathrm{N}_{2} \mathrm{O}$ are available since 2004. MLS measurements are available over a global range of latitudes on a daily basis. The stratospheric $\mathrm{O}_{3}$ product has been validated by Froidevaux et al., (2008). The $\mathrm{N}_{2} \mathrm{O}$ measurements have been validated by Lambert et al., (2007).

Since $2004 \mathrm{ACE}$ has been measuring $\mathrm{O}_{3}, \mathrm{~N}_{2} \mathrm{O}$, and the nitrogen species that constitute the bulk of $\mathrm{NO}_{y}\left(\mathrm{NO}, \mathrm{NO}_{2}\right.$, $\mathrm{HNO}_{3}$, and $\mathrm{N}_{2} \mathrm{O}_{5}$ ). As a solar occultation instrument it, like HALOE, provides $\sim 28-30$ profiles per day in two latitude bands, one at sunrise and one at sunset. The $\mathrm{ACE} \mathrm{O}_{3}$ measurements have been validated by Dupuy et al. (2009), and the $\mathrm{NO}$ and $\mathrm{NO}_{2}$ measurements were validated by Kerzenmacher et al. (2008).

\subsection{The solar cycle and linear trend calculations}

In cases where species are affected by the solar cycle, one of the challenges in interpreting decadal scale trends in the stratosphere is separating these trends from solar cycle induced variations. Model studies provide some guidance as to the expected solar cycle variations in the species of interest. Egorova et al. (2005) used the SOCOL Chemistry Climate Model (CCM) and found that at $30 \mathrm{~km} \mathrm{O}_{3}$ was higher at solar maximum when compared to solar minimum, but that the difference was $<3 \%$. The $\mathrm{N}_{2} \mathrm{O}$ mixing ratio at $30 \mathrm{~km}$ from $30^{\circ} \mathrm{S}$ to $30^{\circ} \mathrm{N}$ was found to be no more than $2 \%$ 
higher at solar minimum compared to solar maximum, and no more $4 \%$ from 30 to $60^{\circ} \mathrm{N}$ and 30 to $60^{\circ} \mathrm{S}$. Schmidt et al. (2010) used the HAMMONIA general circulation and chemistry model, and found an equatorial $\mathrm{O}_{3}$ sensitivity of $\sim 1.4 \pm 0.4 \% 100^{-1}$ solar flux units ( $\mathrm{sfu}$ ), where the difference between the 1989 solar max and the 1986 solar min is $166 \mathrm{sfu}$. The study of Remsberg and Lingenfelser (2010) shows a $3 \%$ ozone maximum-minimum response to the solar cycle at $\sim 35 \mathrm{~km}(\sim 7 \mathrm{hPa})$ from the SAGE II measurements, with results from the HALOE measurements and from model calculations showing a smaller ozone response to the solar cycle. As discussed in Hood and Soukharev (2006), $\mathrm{NO}_{y}$ in the upper stratosphere is also affected by the solar cycle. They place an upper limit of $\sim 10 \%$ on the solar cycle variations in $\mathrm{NO}_{y}$ in the tropical mid-stratosphere. The model calculations in Egorova et al. (2005) show an $\mathrm{NO}_{2}$ solar cycle variation of $<1 \%$, and Nedoluha et al. (1998) show a similarly small variation from the CHEM2D model (Bacmeister et al., 1998).

Throughout this study we will calculate trends based on a function including terms to fit the annual, semi-annual, QBO (quasi-biennial oscillation), plus a constant term and a linear trend term. The QBO terms were calculated using the Center for Climate Prediction 30 and $50 \mathrm{hPa}$ winds anomalies obtained from www.cpc.ncep.noaa.gov/data/indices/. In addition to these terms, we have calculated trends from the HALOE measurements both with and without the inclusion of a solar cycle term, where the solar cycle fit is calculated using the Mg II values obtained from the Laboratory for Atmospheric and Space Physics (LASP) Interactive Solar Irradiance Data Center at lasp.colorado.edu/lisird. We will only show HALOE trend calculations where a solar cycle term has been included, but we have compared trends with and without the solar cycle term and found that the results are similar.

The MLS measurement time series used here extends from 2004 to 2014, and therefore clearly does not extend over a full solar cycle. The linear trend calculations from MLS measurements which will be shown cover the period August 2004 to May 2013. Because solar cycle 24 is particularly weak, the Mg II values in 2013 are comparable to those in 2004, so solar effects are unlikely to cause a trend in the MLS data set used here. In order to provide an estimate of the uncertainty in the trend, which is introduced by the presence of a solar cycle, we will show some MLS results both with and without the inclusion of a solar cycle term. We will show that in the region of greatest interest, near the tropics at $\sim 10 \mathrm{hPa}$, the MLS trends appear to be nearly insensitive to the presence of a solar cycle.

\subsection{Measurements of $\mathrm{O}_{3}$, 1991-2014}

In Fig. 1 we show the annual median $\mathrm{O}_{3}$ anomalies from $5^{\circ} \mathrm{S}$ to $5^{\circ} \mathrm{N}$ as measured by both HALOE and Aura MLS at $10 \mathrm{hPa}$. This figure also shows that the $\mathrm{O}_{3}$ decrease at $10 \mathrm{hPa}$ has occurred gradually over the period shown. There

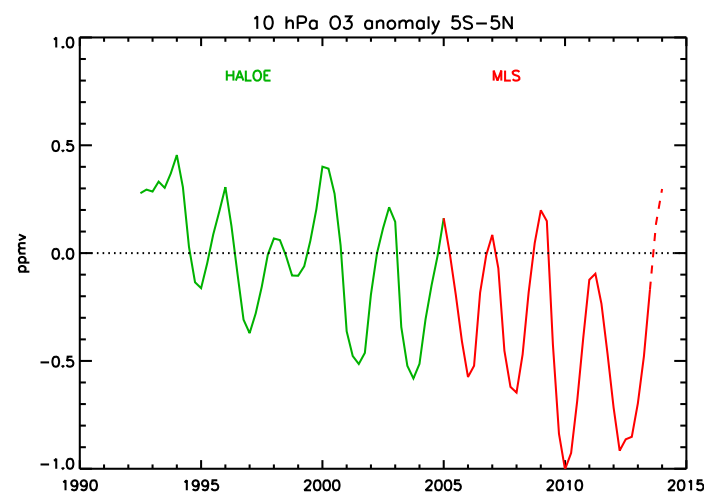

Figure 1. Annual median ozone anomalies at $10 \mathrm{hPa} 5^{\circ} \mathrm{S}-5^{\circ} \mathrm{N}$ from HALOE (green; HALOE data is actually shown on its native grid at $30 \mathrm{~km}$, which is $\sim 10 \mathrm{hPa}$ ) and MLS (red). Annual anomalies are shown four times per year; hence each measurement is included in four data points. The MLS anomalies have been shifted by a constant mixing ratio so that the HALOE and MLS annual anomalies for 2005 (covering the period July 2004-June 2005) agree. The MLS data from July 2013 onwards is indicated dashed in order to indicate that this data will not be used in any of the linear trend calculations to be shown.

have been numerous studies combining $\mathrm{O}_{3}$ time series from multiple satellites to derive long-term trends (e.g., Jones et al., 2009; Kryölä et al., 2013), and there are several projects underway to provide long-term data records of stratospheric composition, so we will not attempt here to produce a combined HALOE-MLS $\mathrm{O}_{3}$ time series for trend calculations. The MLS time series anomalies shown have simply been offset by a shift in mixing ratio so that the anomaly point for 2005 (which covers data taken during the period July 2004 through June 2005) agrees with the HALOE anomaly at that point. The anomalies are calculated by fitting annual and semi-annual cycles to each data set separately and then calculating annual median differences from this fit. The annual anomaly is sampled four times per year so that each point represents an anomaly over either January-December, April-March, July-June, or October-September. Each measurement is therefore included in four data points in the figure. Having removed the annual cycle, the primary variation in $\mathrm{O}_{3}$ in this region is caused by the QBO. In addition to these QBO variations, there is a clear decrease in $\mathrm{O}_{3}$ over the 21 years shown.

An estimate of the uncertainty in these annual medians can be obtained from the standard deviation of the individual anomalies. The average value of $\sigma n^{-1 / 2}$ for the annual median HALOE $\mathrm{O}_{3}$ anomalies is $0.026 \mathrm{ppmv}$. The last annual anomaly has the largest uncertainty with $\sigma n^{-1 / 2}=0.056$ ppmv. For the MLS, which has many more measurements, the largest annual median uncertainty calculated by this method is $0.0027 \mathrm{ppmv}$.

In Fig. 2 we show the linear trend in the global HALOE ozone measurements from 1991 to 2005. Remsberg (2008) 


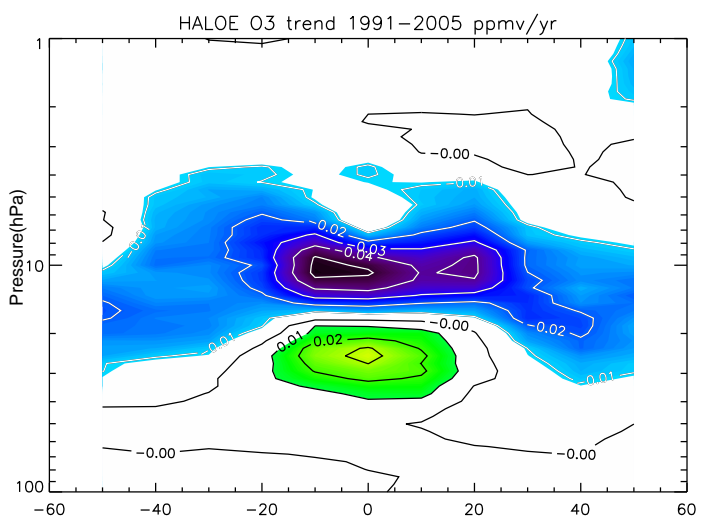

Figure 2. The calculated linear trend in HALOE ozone for 19912005. The HALOE data has been sorted into 11 individual $10^{\circ}$ latitude bins from $55^{\circ} \mathrm{S}$ to $55^{\circ} \mathrm{N}$. Regions where the magnitude of the trend is $<0.01$ ppmv year $^{-1}$ are indicated in white.

show a quite similar figure (their Fig. 13) for linear trends in HALOE $\mathrm{O}_{3}$, but in $\%$ decade $^{-1}$. They found that the trends near $10 \mathrm{hPa}$ from $\sim 25^{\circ} \mathrm{S}$ to $\sim 25^{\circ} \mathrm{N}$ had a confidence interval of $>90 \%$ for their partial tank order correlations (Remsberg et al., 2001). The trend is negative (i.e., $\mathrm{O}_{3}$ is decreasing) near $\sim 10 \mathrm{hPa}$ with the most negative values occurring in the tropics. Most of this study will focus primarily on the causes of this $\mathrm{O}_{3}$ decrease in this region. In general the results are very similar whether or not a solar cycle is included in the fit, but the local tropical minimum at $\sim 4 \mathrm{hPa}$ does not appear when such a term is not included.

HALOE measurements ceased in 2005, and Aura MLS has been providing $\mathrm{O}_{3}$ measurements since 2004. In Fig. 3 we show the linear trend in $\mathrm{O}_{3}$ as measured by MLS. MLS shows that the negative ozone trend in the tropics near $\sim 10 \mathrm{hPa}$ continued from August 2004 to June 2013. Inclusion of the most recent MLS data (from July 2013 to September 2014) does not result in a qualitative change in Fig. 3, but does reduce the magnitude of the measured trends. Again, the $\mathrm{O}_{3}$ linear trends shown in Fig. 3 have been calculated with a solar cycle included in the fit, but the results are very similar with and without a solar cycle term. Several other data sets have also shown decreasing $\mathrm{O}_{3}$ near $10 \mathrm{hPa}$ in the tropics. Kryölä et al. (2013) has shown a decrease for 1997-2011 from SAGE and GOMOS, Gebhardt et al. (2014) for 20022012 using measurements from SCIAMACHY, and Eckert et al. (2014) for 2002-2012 using MIPAS measurements. There is some overlap between the negative HALOE $\mathrm{O}_{3}$ trend (1991-2005) and the positive $\mathrm{SAGE} \mathrm{O}_{3}$ trend shown by (Kryölä et al., 2013; 1984-1997). Given the excellent agreement between SAGE II and HALOE trends (e.g., Nazaryan et al., 2005), and the eruption of Mt. Pinatubo near the middle of the 1984-1997 time series, we expect this difference between the 1984-1997 and 1991-2005 trends is caused by a real change in $\mathrm{O}_{3}$ trends in the tropical $10 \mathrm{hPa}$ region in between 1991 and 1997.

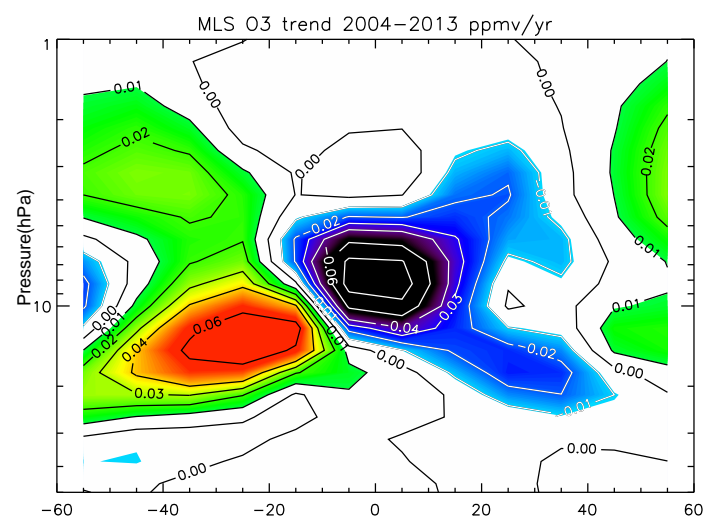

Figure 3. The $\mathrm{O}_{3}$ linear trend calculated from MLS data from August 2004 to May 2013. Contour lines are shown at $\pm 0.01,0.02$, $0.03,0.04,0.06,0.08$ ppmv year $^{-1}$. The MLS data has been sorted into twelve $10^{\circ}$ latitude bins from $60^{\circ} \mathrm{S}$ to $60^{\circ} \mathrm{N}$. Regions where the magnitude of the trend is $<0.01 \mathrm{ppmv}_{\text {year }}{ }^{-1}$ are indicated in white.

While Fig. 1 shows a general decrease in $\mathrm{O}_{3}$ at $10 \mathrm{hPa}$ over the entire HALOE measurement period, and Fig. 3 shows that this trend continued into the MLS measurements period, such trends do not always persist over such extended periods. For example, away from the tropics, the 19912005 HALOE and 2004-2013 MLS trends near $10 \mathrm{hPa}$ show clear, hemispherically dependent, differences. Whereas the HALOE trends show a decrease in $\mathrm{O}_{3}$ at all latitudes near $10 \mathrm{hPa}$, the MLS trends show a sharp increase in $\mathrm{O}_{3}$ at southern mid-latitudes, and a smaller decrease at similar pressure levels in northern mid-latitudes.

Just as the HALOE and MLS trends show clear differences away from the tropics, they also show clear differences in the tropics at other levels. The 1991-2005 HALOE trend shows an increase in tropical $\mathrm{O}_{3}$ near $30 \mathrm{hPa}$, but this is dominated by the strong increase from $\sim 1991$ to 1999 , followed by a period of stability in this region from 1999 to 2005 . The MLS $\mathrm{O}_{3}$ measurements suggest that this period of stability near $30 \mathrm{hPa}$ continues through 2013. However Gebhardt et al. (2014) do show statistically significant $\mathrm{O}_{3}$ increases in the 2002-2012 SCIAMACHY measurements below $30 \mathrm{~km}$ with two local maxima, one near $22 \mathrm{~km}$ and one near $27 \mathrm{~km}$, while Eckert et al. (2014) show an $\mathrm{O}_{3}$ increase from 2002 to 2012 near $22 \mathrm{~km}(\sim 50 \mathrm{hPa})$ but a decrease near $27 \mathrm{~km}$ $(\sim 25 \mathrm{hPa})$ from the MIPAS measurements. In their 1984$1997 \mathrm{O}_{3}$ trends Kryölä et al. (2013) show an increase at $24 \mathrm{~km}$, but a much larger decrease at $21 \mathrm{~km}$. Thus, while several measurements show decadal scale tropical trends near $10 \mathrm{hPa}$, such trends to not appear to be common near $30 \mathrm{hPa}$ nor at other latitudes near $10 \mathrm{hPa}$.

\subsection{The effect of changes in nitrogen species on ozone}

As noted above, $\mathrm{O}_{3}$ in the tropical mid-stratosphere is particularly sensitive to changes in $\mathrm{NO}_{y}$ which result from pho- 


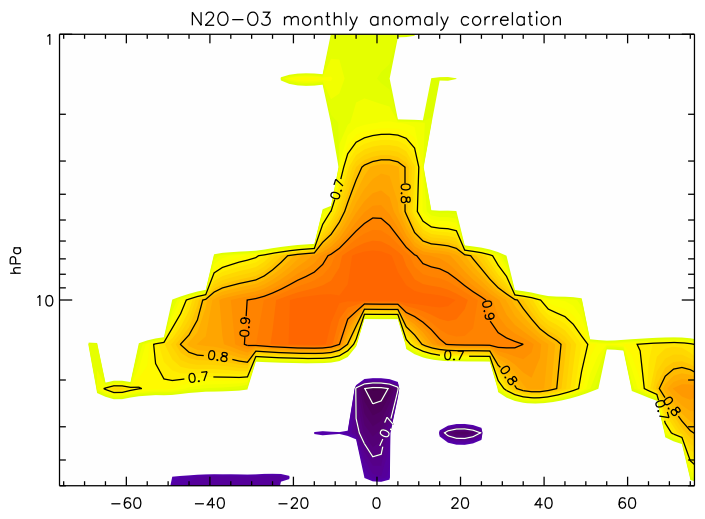

Figure 4. Correlation coefficients between $\mathrm{N}_{2} \mathrm{O}$ and $\mathrm{O}_{3}$ calculated from monthly median anomalies from MLS data as a function of latitude and pressure. Results are shown for regions where the correlation (or anti-correlation) is $>0.6$.

todissociation and oxidation of $\mathrm{N}_{2} \mathrm{O}$ (Olsen et al., 2001), and long-term increases in anthropogenic $\mathrm{N}_{2} \mathrm{O}$ emission are expected to play a significant role in causing future decreases in $\mathrm{O}_{3}$ (Portman et al., 2012). However, $\mathrm{N}_{2} \mathrm{O}$ is also a sensitive indicator of upward transport and, as we show below, these variations in transport lead to a positive, not negative correlation between $\mathrm{N}_{2} \mathrm{O}$ and $\mathrm{O}_{3}$. Figure 4 presents the correlation between MLS $\mathrm{N}_{2} \mathrm{O}$ and $\mathrm{O}_{3}$ from 2004 to 2013 . These correlations are calculated by first finding a zonal monthly median for each year of MLS data and then subtracting from each of these the average MLS monthly median for that month. Note the strongly positive correlation precisely where the observed long-term trends indicate ozone decreases. Figure 5 presents monthly median MLS $\mathrm{N}_{2} \mathrm{O}$ and $\mathrm{O}_{3}$ data from $5^{\circ} \mathrm{S}-$ $5^{\circ} \mathrm{N}$ at $10 \mathrm{hPa}$. The positive correlation between $\mathrm{N}_{2} \mathrm{O}$ and $\mathrm{O}_{3}$ is clearly present on seasonal and interannual timescales and rules out an anthropogenic increase in $\mathrm{N}_{2} \mathrm{O}$ as the cause of the long-term ozone decreases we observe.

This positive correlation between $\mathrm{N}_{2} \mathrm{O}$ and $\mathrm{O}_{3}$ in the tropical middle stratosphere can be readily understood in the context of the relationship between $\mathrm{N}_{2} \mathrm{O}, \mathrm{NO}_{y}$ and $\mathrm{O}_{3}$. This is demonstrated in Fig. 6 which presents ACE measurements of $\mathrm{O}_{3}, \mathrm{~N}_{2} \mathrm{O}$ and the species which make up the bulk of $\mathrm{NO}_{y}$ at $30 \mathrm{~km}(\sim 10 \mathrm{hPa})$ from $10^{\circ} \mathrm{S}-10^{\circ} \mathrm{N}$. While ACE does not provide the daily measurement coverage in the tropics obtained by MLS, it does measure all of the species relevant to the nitrogen chemistry which determines $\mathrm{O}_{3}$ near $\sim 10 \mathrm{hPa}$ in the tropics. Like MLS, ACE shows a strong positive correlation between $\mathrm{N}_{2} \mathrm{O}$ and ozone. ACE also shows the expected anticorrelation resulting from the chemistry of $\mathrm{O}_{3}$ and $\mathrm{NO}_{y}$. Figure $6 \mathrm{c}$ shows the anti-correlation between $\mathrm{NO}_{y}$ and $\mathrm{N}_{2} \mathrm{O}$ without which the correlation between $\mathrm{N}_{2} \mathrm{O}$ and $\mathrm{O}_{3}$ would not exist. This anti-correlation of $\mathrm{N}_{2} \mathrm{O}$ and $\mathrm{NO}_{y}$ can be understood as a coupled chemical/dynamical effect. During periods when upward transport is slower, more $\mathrm{N}_{2} \mathrm{O}$ at a given altitude is dissociated, thus producing more $\mathrm{NO}_{y}$ at that al-

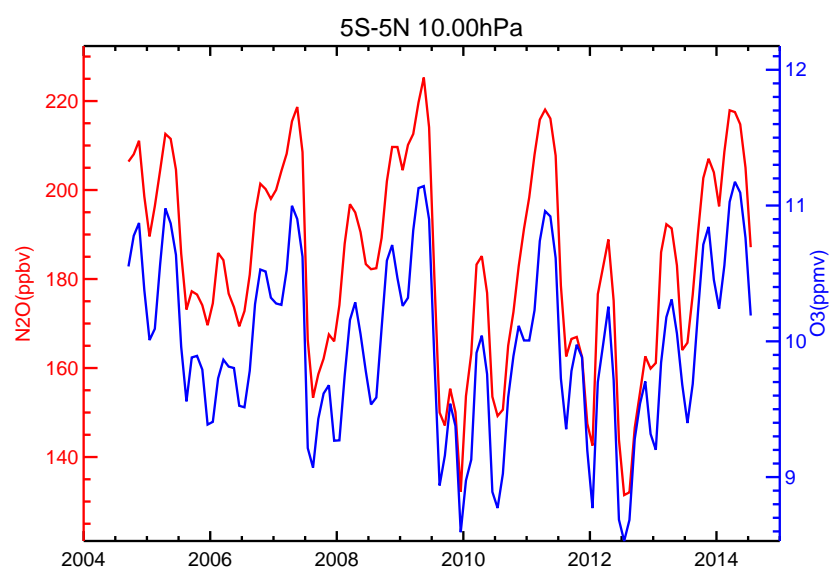

Figure 5. Monthly median $\mathrm{N}_{2} \mathrm{O}$ (red) and $\mathrm{O}_{3}$ (blue) mixing ratios at $10 \mathrm{hPa}$ from MLS measurements between $5^{\circ} \mathrm{S}$ and $5^{\circ} \mathrm{N}$.

titude. We thus conclude that over the period of the MLS measurements, the effect of changes in transport on $\mathrm{N}_{2} \mathrm{O}$ in this region on $\mathrm{NO}_{y}$ and hence $\mathrm{O}_{3}$ dominate any increase in $\mathrm{N}_{2} \mathrm{O}$ due to changing tropospheric emissions.

As indicated in Sect. 2.1, the MLS instrument has been operational for less than a full solar cycle; hence for tropical trend calculations we show results both with and without the inclusion of a solar cycle term. In Fig. 7 we show the calculated profiles as a function of pressure as derived from eight (constant term, two annual terms, two semi-annual terms, two QBO terms, and a linear trend) and nine (including a solar cycle) parameter fits to the monthly median MLS measurements. Figure 7 shows the profiles (the constant terms from the fits) in addition to the linear trend and the net effect of 8 years of such a trend (2004-2005 vs. 2012-2013). The $\mathrm{O}_{3}$ trend results are in good agreement with those shown by Gebhardt et al. (2014) for August 2004-April 2012, where the fastest decreasing trend in $\mathrm{MLS} \mathrm{O}_{3}$ is $\sim 7 \%$ decade $^{-1}$. Gebhardt et al. (2014) show that the MLS trends in $\mathrm{O}_{3}$ are not statistically different from those observed by SCIAMACHY or OSIRIS. While the inclusion of the solar cycle term fit clearly does affect the linear trend at some levels, it does not alter the qualitative result that $\mathrm{O}_{3}$ and $\mathrm{N}_{2} \mathrm{O}$ both show a statistically significant decrease over a similar range of pressures near $10 \mathrm{hPa}$. This further reinforces the conclusion that this decrease in $\mathrm{O}_{3}$ is caused by an increase in $\mathrm{NO}_{y}$ (resulting from increased dissociation of $\mathrm{N}_{2} \mathrm{O}$ ) during this period.

As was shown in Fig. 2, HALOE measurements showed a decrease in $\mathrm{O}_{3}$ from $1992-2005$ at $10 \mathrm{hPa}$ from $5^{\circ} \mathrm{S}-5^{\circ} \mathrm{N}$. While HALOE did not provide measurements of $\mathrm{N}_{2} \mathrm{O}$, and did not provide the full complement of $\mathrm{NO}_{y}$ species that is available from ACE, it did provide measurements of two of the key odd-nitrogen species, $\mathrm{NO}$ and $\mathrm{NO}_{2}$.

In Fig. 8 we show annual median HALOE anomalies in $\mathrm{O}_{3}$ alongside those of $\mathrm{NO}+\mathrm{NO}_{2}$. Because $\mathrm{NO}+\mathrm{NO}_{2}$ has a strong diurnal component (unlike the set of $\mathrm{NO}_{y}$ measurements provided by ACE), the anomalies for both 

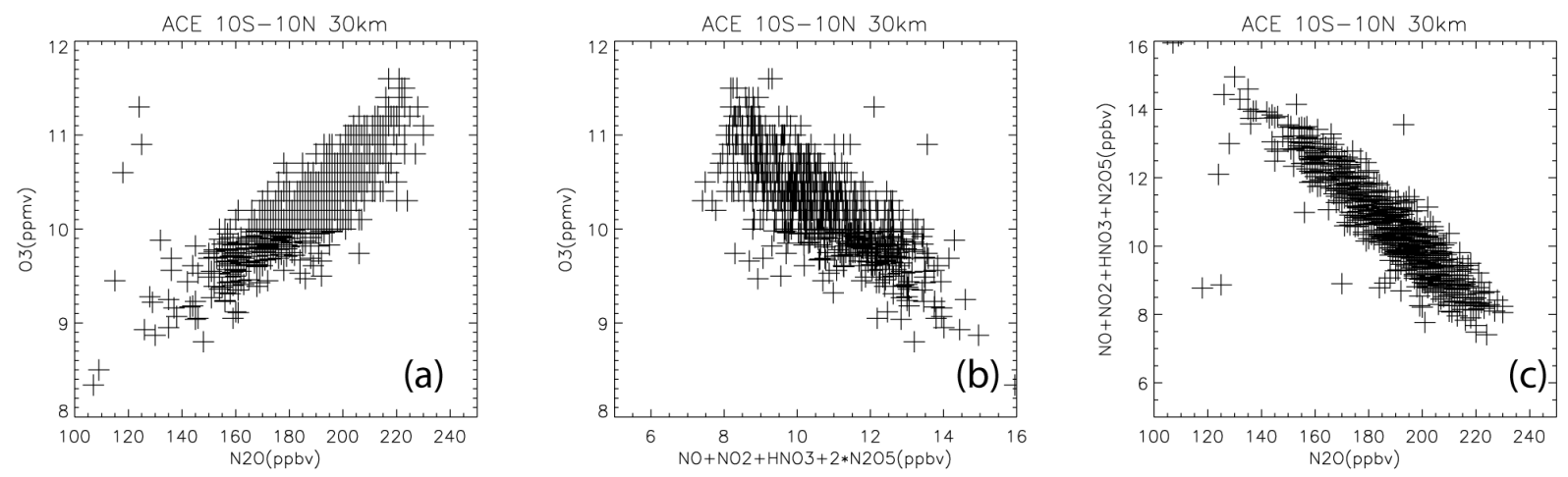

Figure 6. ACE measurements of $\mathrm{O}_{3}, \mathrm{~N}_{2} \mathrm{O}$, and the key members of the $\mathrm{NO}_{y}$ family, $\mathrm{NO}+\mathrm{NO}_{2}+\mathrm{HNO}_{3}+2 \times \mathrm{N}_{2} \mathrm{O}_{5}$. Measurements are shown for $10^{\circ} \mathrm{S}-10^{\circ} \mathrm{N}$ at $30 \mathrm{~km}$. Both sunrise and sunset measurements are included.
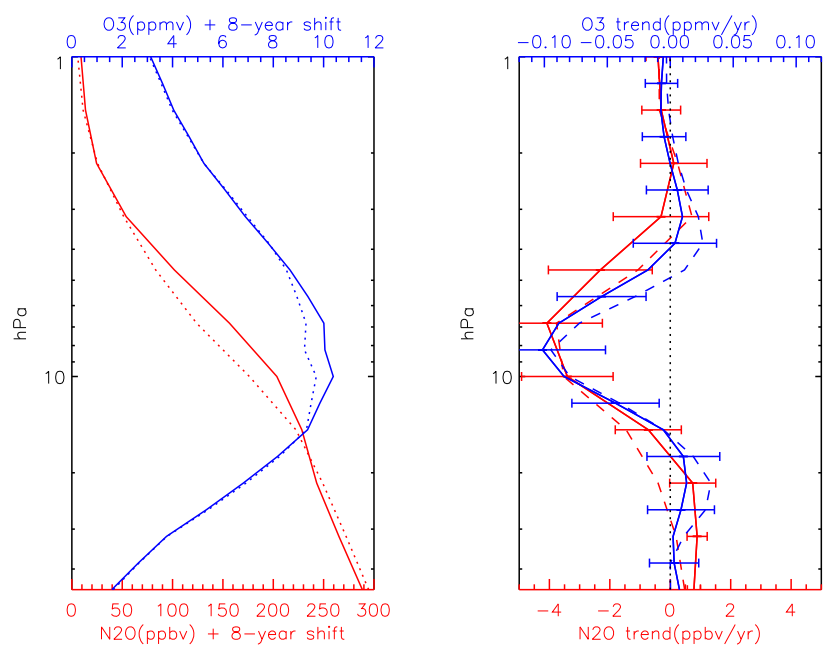

Figure 7. Left hand panel: annual average MLS profiles of $\mathrm{O}_{3}$ (blue; top scale) and $\mathrm{N}_{2} \mathrm{O}$ (red; bottom scale) from $5^{\circ} \mathrm{S}-5^{\circ} \mathrm{N}$. Shown are the constant term derived from the fit to the August 2004-May 2013 MLS measurements (solid), and the same term with an added 8 -year shift (thus approximating the difference between the 20042005 and 2012-2013 MLS annual average) based on the linear trend applied over a period comparable to the length of the MLS data set (dotted). Right hand panel: linear annual trend calculated with a solar cycle term included (solid) and without a solar cycle term (dashed). Error bars $(2 \sigma)$ are similar for fits with and without the solar cycle, and are shown only for the former.

species are calculated separately for sunrise and sunset measurements. We have multiplied the sunset $\mathrm{NO}+\mathrm{NO}_{2}$ measurements by 0.4 so that they fit onto the same scale as the sunrise measurements. The average (maximum) $\sigma n^{-1 / 2}$ value for sunrise $\mathrm{NO}+\mathrm{NO}_{2}$ is $0.064 \mathrm{ppbv}(0.082 \mathrm{ppbv})$, while for the sunset measurements (before multiplication by 0.4$)$ it is $0.122 \mathrm{ppbv}(0.22 \mathrm{ppbv})$. For the $\mathrm{O}_{3}$ sunrise measurements the average (maximum) $\sigma n^{-1 / 2}$ value is $0.045 \mathrm{ppmv}(0.064 \mathrm{ppmv})$, while for the sunset measurements it is $0.049 \mathrm{ppmv}(0.081 \mathrm{ppmv})$.
Figure 8 shows that $\mathrm{NO}+\mathrm{NO}_{2}$ generally was increasing over the course of the HALOE measurements and that this increase tracked the ozone decrease, both on a year-toyear timescale (dominated by the quasi-biennial oscillation, QBO) and over the full 1992-2005 time period. There is a slight ( $\sim$ 3-month) apparent phase-lag between the sunset and sunrise $\mathrm{NO}+\mathrm{NO}_{2}$ measurements from $\sim 1998$ to 2003, which is not apparent in the $\mathrm{O}_{3}$ anomalies and for which we have no explanation. With the exception of this feature, the general consistency between the QBO driven variations in $\mathrm{O}_{3}$ and $\mathrm{NO}+\mathrm{NO}_{2}$, and the trend which is apparent in both the $\mathrm{O}_{3}$ and $\mathrm{NO}+\mathrm{NO}_{2}$ measurements, provides added confidence that the decrease in $\mathrm{O}_{3}$ and the increase in $\mathrm{NO}+\mathrm{NO}_{2}$ measured by HALOE from 1992 to 2005 are both correct and, further, are coupled. As we concluded from the MLS measurements from 2004 to 2013, this change suggests a slowdown in upward transport in this region from 1992 to 2005. Note, this is consistent with the results of Nedoluha et al. (1998) who interpreted the decreases in upper stratospheric $\mathrm{CH}_{4}$ from 1992 to 1996 as linked with a simultaneous increase in $\mathrm{NO}_{2}$ at $30 \mathrm{~km}$. Our results here extend that early result to encompass the entire 13 year UARS mission.

In Fig. 9 we show the calculated linear trends in the HALOE $\mathrm{O}_{3}$ and $\mathrm{NO}+\mathrm{NO}_{2}$ measurements. As in Fig. 8 we separate the HALOE sunrise and sunset measurements, and calculate trends for four separate measurements: sunrise and sunset $\mathrm{O}_{3}$ and sunrise and sunset $\mathrm{NO}+\mathrm{NO}_{2}$. Encouragingly, despite having very different vertical profiles, the shape of the sunrise and sunset $\mathrm{NO}+\mathrm{NO}_{2}$ trend profiles are very similar. The $\mathrm{O}_{3}$ sunrise and sunset trends also agree well, and the pressure level of the minimum of the observed decrease in these $\mathrm{O}_{3}$ measurements corresponds closely with the maximum in the observed increase in the $\mathrm{NO}+\mathrm{NO}_{2}$ measurements. 

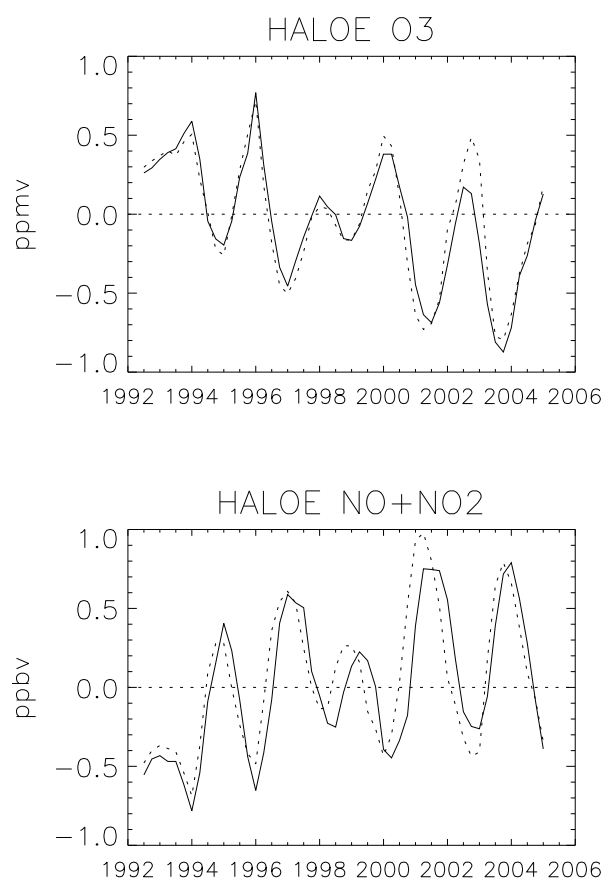

Figure 8. Annual median $\mathrm{HALOE} \mathrm{O}_{3}$ (top) and $\mathrm{NO}+\mathrm{NO}_{2}$ (bottom) anomalies at $10 \mathrm{hPa}$ from $5^{\circ} \mathrm{S}$ to $5^{\circ} \mathrm{N}$. Annual anomalies are shown four times per year; hence, each measurement is included in four data points. Results are shown separately for sunrise (solid) and sunset (dashed). Sunset $\mathrm{NO}+\mathrm{NO}_{2}$ anomalies have been multiplied by 0.4 so that they fit on the same scale as the sunrise anomalies.

\section{Model calculations}

In order to better understand the changes in the observed species we have employed the two-dimensional chemical transport model (CHEM2D; Bacmeister et al., 1998). The model includes parameterized gravity wave and planetary wave drag and is ideal for understanding tracer transport and the response of the global middle atmospheric circulation to external forcings. Compared with those earlier studies, the present model has an improved vertical resolution (1 instead of $2 \mathrm{~km}$ ). CHEM2D's most recent applications have included simulating the solar cycle variations of polar mesospheric clouds (Siskind et al., 2005) and studying the response of stratospheric ozone to both the solar cycle and the tropical quasi-biennial oscillation (McCormack et al., 2007).

We will show results from two model runs, each of which has been integrated for 12 years to ensure stability from yearto-year. Since the goal of the model was to test whether dynamical changes would affect $\mathrm{N}_{2} \mathrm{O}, \mathrm{NO}_{y}$, and $\mathrm{O}_{3}$ at the equator, we introduced a very simple perturbation. The two models differ only in that, in one case, we added a small heat source of $0.3 \mathrm{~K} \mathrm{day}^{-1}$, centered at $18 \mathrm{~km}$ at the equator, similar to Experiment 7 of Bacmeister et al. (1998). In addition, we recognize that the model differences shown represent two equilibrium solutions while the calculated trends show the
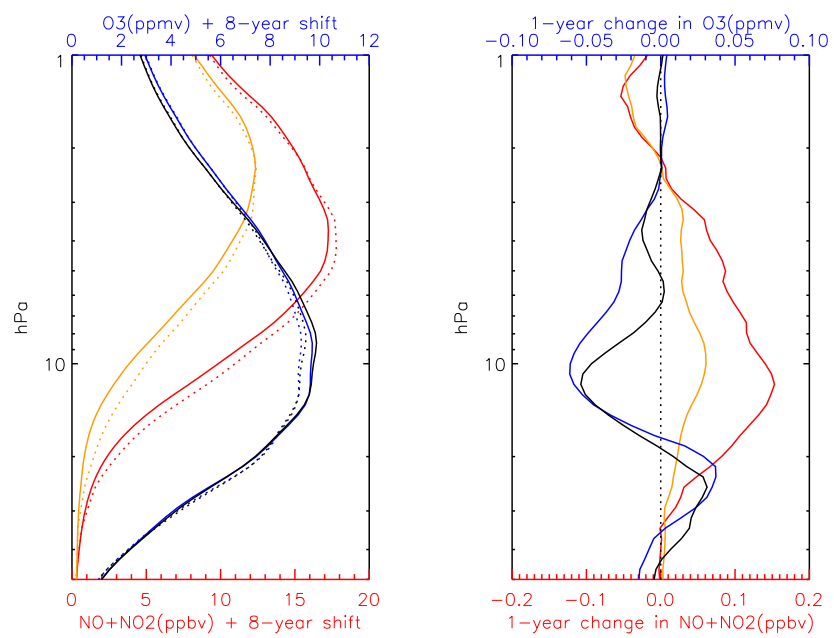

Figure 9. Left hand panel: annual average HALOE profiles of $\mathrm{O}_{3}$ at local sunset (blue; top scale), local sunrise (black; top scale) and $\mathrm{NO}+\mathrm{NO}_{2}$ at local sunset (red; bottom scale), and local sunrise (orange; bottom scale) from $5^{\circ} \mathrm{S}$ to $5^{\circ} \mathrm{N}$. Results are shown for the first year of HALOE measurements (solid) and with an 8-year shift (to allow for comparison with Fig. 7) using the annual average trend shown on the right-hand panel (dashed). Right hand panel: 1-year changes based on linear trends over $5^{\circ} \mathrm{S}-5^{\circ} \mathrm{N}$ calculated from 1991 to 2005 . Line colors are the same as in the left-hand panel.

effects of an atmosphere changing over time. Nonetheless, a comparison of these two models can serve as an indication whether it is possible to reproduce the observed changes in the measured species with a dynamical perturbation.

Figure 10 shows the change in $\mathrm{N}_{2} \mathrm{O}, \mathrm{NO}_{y}$, and $\mathrm{O}_{3}$ at the equator resulting from this dynamical perturbation. The absolute values for these three species at $10 \mathrm{hPa}$ are in very good general agreement with those shown in Fig. 6 from the ACE measurements. The $\mathrm{N}_{2} \mathrm{O}$ chemistry is relatively simple, and $\mathrm{N}_{2} \mathrm{O}$ at all levels is lower for the case of the slower tropical ascent which offers more time for dissociation. At $10 \mathrm{hPa}$ the case with the slower ascent shows $\sim 22$ ppbv less $\mathrm{N}_{2} \mathrm{O}$. Unlike the measurements, however, the $\mathrm{N}_{2} \mathrm{O}$ in the model changes over a deep layer, covering the entire pressure range from $50-1 \mathrm{hPa}$.

The calculated equatorial $\mathrm{N}_{2} \mathrm{O}$ changes shown in Fig. 10 correspond with calculated $\mathrm{O}_{3}$ and $\mathrm{NO}_{y}$ profile changes which are in the same sense and general magnitude as the observations. Thus the calculation with lower $\mathrm{N}_{2} \mathrm{O}$ yields increased $\mathrm{NO}_{y}$ due to increased oxidation. via $\mathrm{N}_{2} \mathrm{O}+\mathrm{O}(1 \mathrm{D})->2 \mathrm{NO}$; the baseline model with $\sim 22 \mathrm{ppbv}$ less $\mathrm{N}_{2} \mathrm{O}$ shows an increase of $\sim 1.3 \mathrm{ppbv}$ in $\mathrm{NO}_{y}$, so $\Delta \mathrm{NO}_{y} / \Delta \mathrm{N}_{2} \mathrm{O} \sim 0.065$. This is similar to the $\Delta \mathrm{NO}_{y} / \Delta \mathrm{N}_{2} \mathrm{O}$ in the ACE measurements in Fig. 6c, which is $\sim 0.75$. Regarding ozone, the baseline model with less heating and $1.3 \mathrm{ppbv}$ greater $\mathrm{NO}_{y}$ shows about $\sim 0.26 \mathrm{ppmv}$ less $\mathrm{O}_{3}$ at $10 \mathrm{hPa}$. This yields a $\Delta \mathrm{O}_{3} / \Delta \mathrm{NO}_{y}$ of $\sim 200$ which is on the order of, but somewhat less than, the observed 

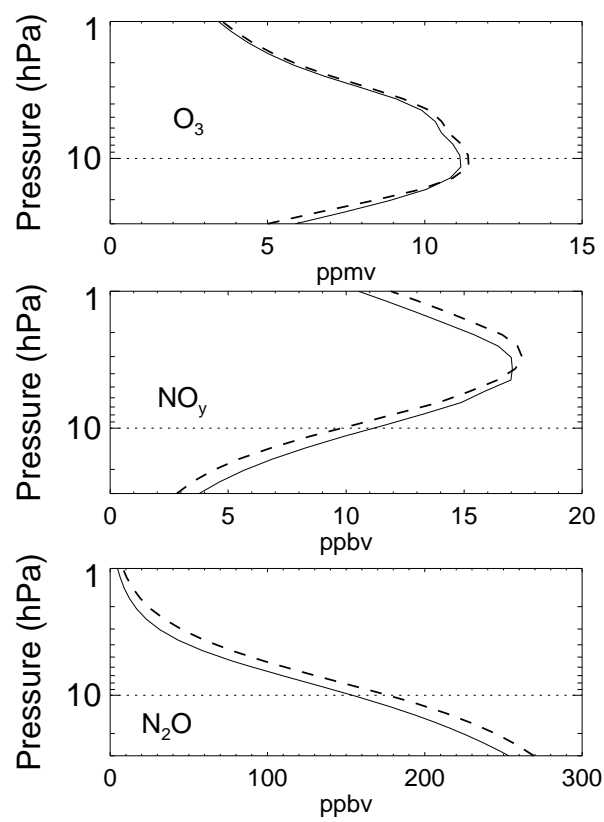

Figure 10. Annual average altitude profiles of $\mathrm{O}_{3}, \mathrm{NO}_{y}$, and $\mathrm{N}_{2} \mathrm{O}$ for the equator. The solid curve is a baseline run, while the dashed curve is a simulation which includes an additional $0.3 \mathrm{~K} \mathrm{day}^{-1}$ heat source in the lowermost stratosphere which acts to increase the tropical upwelling.

$\Delta \mathrm{O}_{3} / \Delta \mathrm{NO}_{y}$ from the ACE measurements (which is closer to $\sim 330$ ). We can also directly compare the calculated quantity $\Delta \mathrm{O}_{3} / \Delta \mathrm{N}_{2} \mathrm{O}$ in the model and in the ACE and MLS measurements; here we also get a somewhat reduced ozone response compared with the observations. Whereas the model shows a $\Delta \mathrm{O}_{3} / \Delta \mathrm{N}_{2} \mathrm{O}$ of $\sim 12$, ACE and MLS both show $\Delta \mathrm{O}_{3} / \Delta \mathrm{N}_{2} \mathrm{O} \sim 25$ ). About $25 \%$ of this difference is because the model $\Delta \mathrm{NO}_{y} / \Delta \mathrm{N}_{2} \mathrm{O}$ sensitivity is slightly less than observed. Also, since our approach towards diurnal averaging requires a specific of a single night-to-day ratio (cf. Summers et al., 1997), it is possible that we are underestimating the diurnally averaged response of $\mathrm{O}_{3}$ to $\mathrm{NO}_{x}$ chemistry, which varies strongly with the time of day. Nevertheless, the qualitative agreement between the model and the ACE and MLS measurements supports the idea that the observed $\mathrm{O}_{3}$ change can be caused by a dynamical perturbation.

While the model runs do support the suggestion that the changes in $\mathrm{O}_{3}$ and $\mathrm{N}_{2} \mathrm{O}$ observed near the equator at $\sim 10 \mathrm{hPa}$ can be caused by a dynamical perturbation, we do note that this particular dynamical perturbation also shows large differences in other regions where the measured trends are small and/or vary in a temporally different manner than do the tropical $10 \mathrm{hPa}$ measurements. No doubt a number of dynamical changes affected $\mathrm{N}_{2} \mathrm{O}$ over the period 1991-2013, and these variations drove changes in $\mathrm{NO}_{x}$ and in turn $\mathrm{O}_{3}$. What we conclude here is that, because of changes in transport, the $\mathrm{N}_{2} \mathrm{O}$ which arrived in this region experienced significantly more dissociation in 2013 than in 2004, and, based on inferences from the $\mathrm{HALOE} \mathrm{O}_{3}$ and $\mathrm{NO}_{x}$ measurements, that this trend was also present throughout much of the HALOE measurement period. We note that there is a burgeoning literature debating the possibility of changes in the stratospheric circulation (cf. Butchart, 2014 and references therein). The results presented here may serve as a useful constraint for these analyses of long-term stratospheric variability.

\section{Summary}

Ozone measurements from HALOE and MLS show a longterm decrease in $\mathrm{O}_{3}$ in the tropical mid-stratosphere near the peak of the $\mathrm{O}_{3}$ mixing ratio. $\mathrm{O}_{3}$ in this region is very sensitive to variations in $\mathrm{NO}_{y}$, and the observed decrease in $\mathrm{O}_{3}$ can be understood in terms of the effects of increasing $\mathrm{NO}_{y}$. From MLS and ACE measurements, we conclude that the $\mathrm{NO}_{y}$ variations are the result of a decrease in $\mathrm{N}_{2} \mathrm{O}$ from 1992 to 2012 resulting from changes in the dynamics over this period. Using a 2-D model, we show that a perturbation of the dynamics results in changes in $\mathrm{N}_{2} \mathrm{O}, \mathrm{NO}_{y}$, and $\mathrm{O}_{3}$ which are qualitatively consistent with the observed trends. In future it would be interesting to study $\mathrm{N}_{2} \mathrm{O}, \mathrm{NO}_{y}$, and $\mathrm{O}_{3}$ variations in this region in more sophisticated 3D models.

A feature of particular interest for future work is the increase in $\mathrm{O}_{3}$ observed in the Southern Hemisphere midstratosphere by MLS. Both the overall increase in $\mathrm{O}_{3}$ in this region as well as the short-timescale variations are well correlated with changes in $\mathrm{N}_{2} \mathrm{O}$, suggesting that this $\mathrm{O}_{3}$ variation is also dynamically controlled.

Acknowledgements. This project was funded by NASA under the Upper Atmosphere Research Program, by the Naval Research Laboratory, and by the Office of Naval Research. Work at the Jet Propulsion Laboratory, California Institute of Technology, was carried out under a contract with the National Aeronautics and Space Administration. MLS and HALOE data are available from the NASA Goddard Earth Science Data Information and Services Center (acdisc.gsfc.nasa.gov). ACE-FTS data is available at www.ace.uwaterloo.ca.

Edited by: M. Weber

\section{References}

Aquila, V., Oman, L. D., Stolarski, R., Douglass, A. R., and Newman, P. A.: The Response of Ozone and Nitrogen Dioxide to the Eruption of Mt. Pinatubo at Southern and Northern Midlatitudes, J. Atmos. Sci., 70, 894-900, 2013.

Bacmeister, J. T., Siskind, D. E., Summers, M. E., and Eckermann, S. D.: Age of air in a zonally averaged two-dimensional model, J. Geophys. Res., 103, 11263-11288, 1998.

Bourassa, A. E., Degenstein, D. A., Randel, W. J., Zawodny, J. M., Kyrölä, E., McLinden, C. A., Sioris, C. E., and Roth, C. Z.: Trends in stratospheric ozone derived from merged SAGE 
II and Odin-OSIRIS satellite observations, Atmos. Chem. Phys., 14, 6983-6994, doi:10.5194/acp-14-6983-2014, 2014.

Brasseur, G. P. and Solomon, S.: Aeronomy of the Middle Atmosphere, D. Reidel press, chapter 5, 1986.

Butchart, N.: The Brewer-Dobson circulation, Rev. Geophys., 52, 157-184, doi:10.1002/2013RG000448, 2014.

Damadeo, R. P., Zawodny, J. M., and Thomason, L. W.: Reevaluation of stratospheric ozone trends from SAGE II data using a simultaneous temporal and spatial analysis, Atmos. Chem. Phys., 14, 13455-13470, doi:10.5194/acp-14-13455-2014, 2014.

Dupuy, E., Walker, K. A., Kar, J., Boone, C. D., McElroy, C. T., Bernath, P. F., Drummond, J. R., Skelton, R., McLeod, S. D., Hughes, R. C., Nowlan, C. R., Dufour, D. G., Zou, J., Nichitiu, F., Strong, K., Baron, P., Bevilacqua, R. M., Blumenstock, T., Bodeker, G. E., Borsdorff, T., Bourassa, A. E., Bovensmann, H., Boyd, I. S., Bracher, A., Brogniez, C., Burrows, J. P., Catoire, V., Ceccherini, S., Chabrillat, S., Christensen, T., Coffey, M. T., Cortesi, U., Davies, J., De Clercq, C., Degenstein, D. A., De Mazière, M., Demoulin, P., Dodion, J., Firanski, B., Fischer, H., Forbes, G., Froidevaux, L., Fussen, D., Gerard, P., GodinBeekmann, S., Goutail, F., Granville, J., Griffith, D., Haley, C. S., Hannigan, J. W., Höpfner, M., Jin, J. J., Jones, A., Jones, N. B., Jucks, K., Kagawa, A., Kasai, Y., Kerzenmacher, T. E., Kleinböhl, A., Klekociuk, A. R., Kramer, I., Küllmann, H., Kuttippurath, J., Kyrölä, E., Lambert, J.-C., Livesey, N. J., Llewellyn, E. J., Lloyd, N. D., Mahieu, E., Manney, G. L., Marshall, B. T., McConnell, J. C., McCormick, M. P., McDermid, I. S., McHugh, M., McLinden, C. A., Mellqvist, J., Mizutani, K., Murayama, Y., Murtagh, D. P., Oelhaf, H., Parrish, A., Petelina, S. V., Piccolo, C., Pommereau, J.-P., Randall, C. E., Robert, C., Roth, C., Schneider, M., Senten, C., Steck, T., Strandberg, A., Strawbridge, K. B., Sussmann, R., Swart, D. P. J., Tarasick, D. W., Taylor, J. R., Tétard, C., Thomason, L. W., Thompson, A. M., Tully, M. B., Urban, J., Vanhellemont, F., Vigouroux, C., von Clarmann, T., von der Gathen, P., von Savigny, C., Waters, J. W., Witte, J. C., Wolff, M., and Zawodny, J. M.: Validation of ozone measurements from the Atmospheric Chemistry Experiment (ACE), Atmos. Chem. Phys., 9, 287-343, doi:10.5194/acp-9-287-2009, 2009

Eckert, E., von Clarmann, T., Kiefer, M., Stiller, G. P., Lossow, S., Glatthor, N., Degenstein, D. A., Froidevaux, L., GodinBeekmann, S., Leblanc, T., McDermid, S., Pastel, M., Steinbrecht, W., Swart, D. P. J., Walker, K. A., and Bernath, P. F.: Drift-corrected trends and periodic variations in MIPAS IMK/IAA ozone measurements, Atmos. Chem. Phys., 14, 25712589, doi:10.5194/acp-14-2571-2014, 2014.

Egorova, T., Rozanov, E., Zubov, V., Schmutz, W., and Peter, Th.: Influence of solar 11-year variability on chemical composition of the stratosphere and mesosphere simulated with a chemistryclimate model, Adv. Space Res., 35, 451-457, 2005.

Froidevaux, L., Jiang, Y. B., Lambert, A., Livesey, N. J., Read, W. G., Waters, J. W., Browell, E. V., Hair, J. W., Avery, M. A., McGee, T. J., Twigg, L. W., Sumnicht, G. K., Jucks, K. W., Margitan, J. J., Sen, B., Stachnik, R. A., Toon, G. C., Bernath, P. F., Boone, C. D., Walker, K. A., Filipiak, M. J., Harwood, R. S., Fuller, R. A., Manney, G. L., Schwartz, M. J., Daffer, W. H., Drouin, B. J., Cofield, R. E., Cuddy, D. T., Jarnot, R. F., Knosp, B. W., Perun, V. S., Snyder, W. V., Stek, P. C., Thurstans, R. P., and Wagner, P. A.: Validation of Aura Microwave Limb
Sounder stratospheric ozone measurements, J. Geophys. Res., 113, D15S20, doi:10.1029/2007JD008771, 2008.

Gebhardt, C., Rozanov, A., Hommel, R., Weber, M., Bovensmann, H., Burrows, J. P., Degenstein, D., Froidevaux, L., and Thompson, A. M.: Stratospheric ozone trends and variability as seen by SCIAMACHY from 2002 to 2012, Atmos. Chem. Phys., 14, 831-846, doi:10.5194/acp-14-831-2014, 2014.

Hood, L. L. and Soukharev, B. E.: Solar induced variations of odd nitrogen: Multiple regression analysis of UARS HALOE data, Geophys. Res. Lett, 33, L22805, doi:10.1029/2006GL028122, 2006.

Jones, A., Urban, J., Murtagh, D. P., Eriksson, P., Brohede, S., Haley, C., Degenstein, D., Bourassa, A., von Savigny, C., Sonkaew, T., Rozanov, A., Bovensmann, H., and Burrows, J.: Evolution of stratospheric ozone and water vapour time series studied with satellite measurements, Atmos. Chem. Phys. Discuss., 9, 11571209, doi:10.5194/acpd-9-1157-2009, 2009.

Kerzenmacher, T., Wolff, M. A., Strong, K., Dupuy, E., Walker, K. A., Amekudzi, L. K., Batchelor, R. L., Bernath, P. F., Berthet, G., Blumenstock, T., Boone, C. D., Bramstedt, K., Brogniez, C., Brohede, S., Burrows, J. P., Catoire, V., Dodion, J., Drummond, J. R., Dufour, D. G., Funke, B., Fussen, D., Goutail, F., Griffith, D. W. T., Haley, C. S., Hendrick, F., Höpfner, M., Huret, N., Jones, N., Kar, J., Kramer, I., Llewellyn, E. J., López-Puertas, M., Manney, G., McElroy, C. T., McLinden, C. A., Melo, S., Mikuteit, S., M urtagh, D., Nichitiu, F., Notholt, J., Nowlan, C., Piccolo, C., Pommereau, J.-P., Randall, C., Raspollini, P., Ridolfi, M., Richter, A., Schneider, M., Schrems, O., Silicani, M., Stiller, G. P., Taylor, J., Tétard, C., Toohey, M., Vanhellemont, F., Warneke, T., Zawodny, J. M., and Zou, J.: Validation of $\mathrm{NO}_{2}$ and NO from the Atmospheric Chemistry Experiment (ACE), Atmos. Chem. Phys., 8, 5801-5841, doi:10.5194/acp-8-5801-2008, 2008.

Kyrölä, E., Laine, M., Sofieva, V., Tamminen, J., Päivärinta, S.-M., Tukiainen, S., Zawodny, J., and Thomason, L.: Combined SAGE II-GOMOS ozone profile data set for 1984-2011 and trend analysis of the vertical distribution of ozone, Atmos. Chem. Phys., 13, 10645-10658, doi:10.5194/acp-13-10645-2013, 2013.

Lambert, A., Read, W. G., Livesey, N. J., Santee, M. L., Manney, G. L., Froidevaux, L., Wu, D. L., Schwartz, M. J., Pumphrey, H. C., Jimenez, C. G., Nedoluha, E., Cofield, R. E., Cuddy, D. T., Daffer, W. H., Drouin, B. J., Fuller, R. A., Jarnot, R. F., Knosp, B. W., Pickett, H. M., Perun, V. S., Snyder, W. V., Stek, P. C., Thurstans, R. P., Wagner, P. A., Waters, J. W., Jucks, K. W., Toon, G. C., Stachnik, R. A., Bernath, P. F.,Boone, C. D., Walker, K. A., Urban, J. D., Murtagh, J., Elkins, W., and Atlas, E.: Validation of the Aura Microwave Limb Sounder middle atmosphere water vapor and nitrous oxide measurements, J. Geophys. Res., 112, D24S36, doi:10.1029/2007JD008724, 2007.

McCormack, J. P., Siskind, D. E., and Hood, L. L.: Solar-QBO interaction and its impact on stratospheric ozone in a zonally averaged photochemical transport model of the middle atmosphere, J. Geophys. Res., 112, D16109, doi:10.1029/2006JD008369, 2007.

Nazaryan, H., McCormick, M. P., and Russell, III, J. M.: New studies of SAGE II and HALOE ozone profile and longterm change comparisons, J. Geophys. Res., 110, D09305, doi:10.1029/2004JD005425, 2005.

Nedoluha, G. E., Siskind, D. E., Bacmeister, J. T., Bevilacqua, R. M., and Russell III, J. M.: Changes in upper stratospheric $\mathrm{CH}_{4}$ 
and $\mathrm{NO}_{2}$ as measured by HALOE and implications for changes in transport, Geophys. Res. Lett., 25, 987-990, 1998.

Newchurch, M. J., Yang, E.-S., Cunnold, D. M., Reinsel, G. C., Zawodny, J. M., and Russell III, J. M.: Evidence for slowdown in stratospheric ozone loss: first stage of ozone recovery, J. Geophys. Res., 108, 4507, ACH 12-1-12-13, doi:10.1029/2003JD003471, 2003.

Olsen, S. C., McLinden, C. A., and Prather, M. J.: Stratospheric $\mathrm{N}_{2} \mathrm{O}-\mathrm{NO}_{y}$ system: Testing uncertainties in a three-dimensional framework, J. Geophys. Res., 106, 28771-28784, 2001.

Plummer, D. A., Scinocca, J. F., Shepherd, T. G., Reader, M. C., and Jonsson, A. I.: Quantifying the contributions to stratospheric ozone changes from ozone depleting substances and greenhouse gases, Atmos. Chem. Phys., 10, 8803-8820, doi:10.5194/acp-108803-2010, 2010.

Portmann, R. W., Daniel, J. S., and Ravishankara, A. R.: Stratospheric ozone depletion due to nitrous oxide: influences of other gases, Philos. T. Roy. Soc. B, 367, 1256-1264, doi:10.1098/rstb.2011.0377, 2012.

Randel, W. J., Wu, F., Russell III J. M., Zawodny, J. M., and Nash, J.: Interannual changes in stratospheric constituents and global circulation derived from satellite data, in: Atmospheric Science Across the Stratopause, Geophys. Monogr. Ser., 123, 271-285, AGU, Washington, D. C., 2000.

Ravishankara, A. R., Daniel, J. S., and Portmann, R. W.: Nitrous Oxide $\left(\mathrm{N}_{2} \mathrm{O}\right)$ : The dominant ozone-depleting substance emitted in the 21st century, Science, 326, 123-125, doi:10.1126/science.1176985, 2009.
Remsberg, E. and Lingenfelser, G.: Analysis of SAGE II ozone of the middle and upper stratosphere for its response to a decadal-scale forcing, Atmos. Chem. Phys., 10, 11779-11790, doi:10.5194/acp-10-11779-2010, 2010.

Remsberg, E. E., Bhatt, P. P., and Deaver, L. E.: Ozone changes in the lower stratosphere from the halogen occultation experiment for 1991 through 1999, J. Geophys. Res., 106, 1639-1653, doi:10.1029/2000JD900596, 2001.

Remsberg, E. E.: On the response of Halogen Occultation Experiment (HALOE) stratospheric ozone andtemperature to the 11-year solar cycle forcing, J. Geophys. Res., 113, D22304, doi:10.1029/2008JD010189, 2008.

Schmidt, H., Brasseur, G. P., and Giorgetta, M. A.: Solar cycle signal in a general circulation and chemistry model with internally generated quasi-biennial oscillation, J. Geophys. Res., 115, D00I14, doi:10.1029/2009JD012542, 2010.

Siskind, D. E., Stevens, M. H., and Englert, C. R.: A model study of global variability in mesospheric cloudiness, J. Atm. Solar.-Terr. Phys., 67, 501-513, 2005.

Summers, M. E., Siskind, D. E., Bacmeister, J. T., Conway, R. R., Zasadil, S. E., and Strobel, D. F.: Seasonal variation of middle atmospheric $\mathrm{CH}_{4}$ and $\mathrm{H}_{2} \mathrm{O}$ with a new chemical-dynamical model, J. Geophys. Res., 102, 3503-3526, 1997.

Yang, E.-S., Cunnold, D. M., Salawitch, R. J., McCormick, M. P., Russell III, J. M., Zawodny, J. M., Oltmans, S., and Newchurch, M. J.: Attribution of recovery in lower stratospheric ozone, J. Geophys. Res., 111, D17309, doi:10.1029/2005JD006371, 2006. 